\title{
PENERAPAN PROJECT BASED LEARNING (PBL) DALAM PEMBELAJARAN MENYIMAK ELEMENTS OF PRONUNCIATION
}

\author{
Imelda Darmayanti Manurung \\ Program Studi Pendidikan Bahasa Inggris, Fakultas Keguruan dan Ilmu \\ Pendidikan, Universitas Muhammadiyah Sumatera \\ imeldadarmayanti@umsu.ac.id
}

\begin{abstract}
Abstrak
Penelitian ini dilakukan berdasarkan kesulitan yang dihadapi mahasiswa dalam menyimak element of pronunciation dikarenakan sistem pelafalan dalam bahasa Inggris berbeda dengan sistem ejaan yang berakibat pada rendahnya haasil belajar menyimak pada materi tersebut. Untuk itu, penelitian ini bertujuan untuk meningkatkan hasil belajar menyimak mahasiswa dengan menerapkan metode Project Based Learning. Penelitian ini menggunakan desain penelitian tindakan kelas yang dilakukan dalam dua siklus. Subjek penelitian ini adalah mahasiswa pendidikan bahasa Inggris, semester dua kelas A pagi yang berjumlah 44 orang yang dipilih berdasarkan teknik purposive sampling. Data dianalisa berdasarkan hasil pre-tes dan post-tes, serta observasi yang dilakukan selama proses pembelajaran. Perbandingan hasil tes menunjukkan ada peningkatan kemampuan menyimak mahasiswa pada materi elements of pronunciation dari $45 \%$ pada pre-tes, menjadi $70 \%$ pada post test siklus pertama, dan $91 \%$ pada post test siklus kedua. Peningkatan kemampuan mencakup penguasaan pada tekanan (stress), irama (rhythm), jeda (juncture), dan intonasi (intonation).
\end{abstract}

Kata Kunci: project based learning, menyimak, pelafalan

\begin{abstract}
This research was conducted based on the difficulties faced by students in listening to the element of pronunciation because the pronunciation system in English is different from the spelling system itself which results in the low result of learning to listen to the material. For this reason, this study aims to improve student learning outcomes by applying the Project Based Learning method. This study uses a classroom action research design conducted in two cycles. The subjects of this study were English language education students, second semester A morning classes, which consists of 44 students. It was taken by using purposive sampling technique. Data is analyzed based on the results of pre-tests and post-tests, as well as observations made during the learning process. Comparison of test results showed that there was an increase in students' listening ability in material elements of pronunciation from $45 \%$ in pre-test, to $70 \%$ in the first cycle post test, and $91 \%$ in the second cycle post test. The imrovement of listening ability includes the mastery of stress, rhythm, juncture, and intonation.
\end{abstract}

Keywords: project-based learning, listening, pronunciation 


\section{PENDAHULUAN}

Keterampilan menyimak merupakan satu dari empat keterampilan berbahasa yang wajib dikuasai oleh pembelajar bahasa, terutama pembelajar bahasa kedua. Keterampilan menyimak di prodi Pendidikan Bahasa Inggris Universitas Muhammadiyah Sumatera Utara didistribusikan ke dalam 3 semester, dengan tingkkat keterampilan yang berbeda-beda. Salah satu materi dari keterampilan menyimak yang diajarkan adalah elements of pronunciation. Pada materi ini mahasiswa diharapkan untuk dapat menguasai bagian-bagian pelafalan bahasa Inggris yaitu tekanan (stress), irama (rhythm), jeda (juncture), dan intonasi (intonation). Dengan penguasaan dasar pada bagian-bagian pelafalan ini diharapkan kedepannya mahasiswa dapat memahami teks lisan yang diberikan dalam berbagai jenis teks baik berbentuk monolog maupun dialog. Tetapi kenyataan di lapangan, kemampuan mahasiswa dalam materi ini sangat rendah.

Rendahnya kemampuan mahasiswa dalam materi ini berakibat pada rendahnya hasil akhir belajar mahasiswa dan menimbulkan kesulitan-kesulitan dalam mengikuti materi selanjutnya. Untuk menghindari hal tersebut, dilakukanlah observasi awal guna menentukan pokok permasalahan dan cara penyelesaiannya. Hasil observasi awal menunjukkan beberapa permasalahan yang dihadapi oleh mahasiswa yaitu:

1. Perbedaan sistem ejaan bahasa Inggris dengan bahasa Indonesia.

2. Sistem pelafalan bahasa Indonesia yang berbeda dengan bahasa Inggris.

3. Kurangnya pemahaman mahasiswa terhadap elements of pronunciation itu sendiri.

4. Kegiatan belajar mengajar yang masih kurang melibatkan mahasiswa dalam mencari sumber belajar.

5. Kurangnya motivasi belajar mahasiswa karena menganggap materi yang diajarkan tidak diterapkan dalam kehidupan sehari-hari sehingga dirasakan kurang bermanfaat. 
Berdasarkan permasalahan tersebut, maka diperlukan suatu metode pembelajaran yang dapat melibatkan semua mahasiswa dalam mencari sumber belajar sehingga dengan sendirinya mereka terlibat langsung dalam memecahkan masalah tersebut di atas.

Salah satu metode yang tepat untuk diterapkan dalam mengatasi masalah tersebut adalah Project Based Learning (PBL). Project Based Learning merupakan suatu metode yang melibatkan mahasiswa secara aktif di dalam proses pembelajaran dimana mahasiswa diminta untuk mengerjakan suatu proyek berdasarkan permasalahan yang dihadapi dalam pembelajaran yang hasil akhirnya adalah sebuah karya unjuk kerja. (Colley, 2008:23, dalam Lisminingsih, 2010:112). Selain itu, Project Based Learning juga dapat meningkatkan komunikasi dan aktivitas belajar mahasiswa (Ani Ismayani dan Nuryanti, 2016:713).

Dalam pembelajaran menyimak ini mahasiswa diminta untuk mencari sumber belajar berupa video dan audio yang berhubungan dengan bagian-bagian pelafalan yaitu tekanan, irama, jeda, dan intonasi dalam bahasa Inggris dari berbagai sumber seperti youtube dan laman daring lainnya, kemudian mempelajari bahan belajar tersebut, dan mempraktekkannya di depan kelas. Materi yang diberikan disesuaikan dengan sub capaian pembelajaran dan kompetensi pembelajaran yang diharapkan. Dengan demikian diharapkan mahasiswa mendapatkan pengalaman belajar yang menyenangkan serta meningkatkan rasa keingintahuan mereka terhadap materi yang akan dijarkan lebih dalam lagi. Hal ini sejalan dengan hasil penelitian Suhartatik dan Adi (2014:85) yang menyatakan bahwa Problem Based Learning dapat menyelesaikan masalah-masalah dalam pembelajaran, serta dapat meningkatkan kreativitas siswa dalam belajar bahasa Inggris. Project Based Learning juga dapat meningkatkan keterampilan dan kemampuan menyimak mahasiswa (Manurung, 2016:153).

Berdasarkan hal di atas, maka penelitian ini bertujuan untuk meningkatkan hasil belajar menyimak mahasiswa khususnya dalam materi elements of pronunciation dengan menerapkan metode Project Based Learning. Diharapkan hasil dari penelitian ini nantinya dapat bermanfaat bagi pengajar lainnya sebagai 
bahan perbandingan dan sumber rujukan dalam menerapkan Project Based Learning pada materi lainnya.

\section{METODE}

Penelitian didisain dengan menggunakan penelitian tindakan kelas (PTK) karena penelitian ini bertujuan untuk meningkatkan kemampuan mahasiswa dalam menyimak bagian-bagian pelafalan. Penelitian Tindakan Kelas bertujuan untuk mengatasi dan mencari pemecahan masalah yang spesifik dan praktis untuk meningkatkan kualitas dari proses pembelajaran yang terjadi di dalam kelas, yang dapat diukur melalui peningkatan kemampuan mahasiswa. Penelitian tindakan kelas merupakan sebuah cara bagi seseorang atau suatu kelompok dalam mengorganisasikan sebuah kondisi, sehingga mereka mendapatkan pengalaman, dan pengalaman tersebut juga dapat diakses oleh orang lain untuk meningkatkan kualitas proses belajar mengajar. Penelitian ini dilakukan oleh pengajar di dalam kelasnya sendiri yang bertujuan untuk memperbaiki cara mengajar dan meningkatkan hasil belajar pembelajar (Paizaluddin, 2013:8).

\section{A. Subjek Penelitian}

Subjek dari penelitian ini adalah mahasiswa semester dua Kelas A-pagi, Prodi Pendidikan Bahasa Inggris, Fakultas Keguruan dan Ilmu Pendidikan, Universitas Muhammadiyah Sumatera Utara, yang dipilih dengan menggunakan purposive sampling. Adapun alasan pemilihan kelas tersebut didasarkan atas beberapa pertimbangan; nilai rata-rata kelas pada pre-test materi menyimak bagianbagian dari pelafalan terendah dari empat kelas lainnya, kurangnya minat dan motivasi mereka dalam mengikuti kegiatan belajar mengajar yang dikarenakan kesulitan dalam membedakan bunyi-bunyi suara pembeda dalam bahasa Inggris dan berbedanya sistem pelafalan bahasa Inggris dengan bahasa Indonesia.

\section{B. Instrumen Penelitian}

Instrumen dari penelitan ini adalah tes dan pengamatan. Tes yang diberikan adalah tes menyimak untuk membedakan berbagai jenis stress, rhythm, juncture, 
dan intonation pada berbagai bentuk kata, frasa, dan kalimat sederhana. Pengamatan dilakukan guna melihat apakah mahasiswa mampu mengidentifikasi kata atau jenis-jenis kata berdasarkan pelafalannya, menyebutkan arti/pengertian sebuah kalimat atau ekspresi berdasarkan pelafalannya, mengidentifikasi jenis ujaran dan jenis emosi pembicara berdasarkan pelafalannya.

\section{Prosedur Penelitian}

Prosedur penelitian ini menggunakan desain Self-Reflective spiral yang meliputi perencanan (planning), penerapan perencanaan (acting), pengamatan (observation), refleksi (reflecting) dan kemudian perencanaan kembali (replanning) untuk tahapan selanjutnya implementation, observasi, dan refleksi (Cohen, Manion, dan Morrison, 20017:20013) pada siklus berikutnya. Penetapan kriteria keberhasilan dari penelitian ini didasarkan pada ketentuan penilaian yang ditetapkan oleh pihak universitas, Universitas Muhammadiyah Sumatera Utara, yaitu $80 \%$ dari mahasiswa mendapat nilai minimal 60 atau $\mathrm{C}+$.

D. Teknik Pengumpulan Data

Data dalam penelitian ini diperoleh dari hasil tes yang diberikan kepada mahasiswa yang meliputi:

1. Tes, yang terdiri atas

a. Pre-tes, yang diberikan di awal pembelajaran bertujuan untuk mengetahui tingkat kemampuan awal mahasiswa dalam menyimak bagian-bagian pelafalan dan untuk menentukan strategi pembelajaran yang tepat yang akan diterapkan dalam proses belajar, berupa tes menyimak ujaran-ujaran lisan berupa kata frasa, dan kalimat, dan

b. Post-tes, yang diberikan di akhir siklus, yang nantinya akan menentukan berlanjut atau berakhirnya siklus, serta perbaikan-perbaikan yang perlu dilakukan dalam proses pembelajaran.

2. Hasil observasi, indikator observasi harus memenuhi indikator yang ditetapkan berdasarkan sub capaian matakuliah. 


\section{E. Teknik Analisis Data}

Data yang telah diperoleh dalam penelitian ini dianalisis dengan dua cara.

1. Untuk mengetahui hasil tes setiap mahasiswa, maka dihitung jumlah jawaban benar dibagi dengan jumlah soal. Kemudian untuk menentukan tingkat keberhasilan yaitu $80 \%$ dari siswa mendapat nilai minimal 60, jumlah siswa yang mendapat nilai lebih besar sama dengan 60 dibagi dengan seluruh jumlah mahasiswa dikali dengan $100 \%$.

Untuk hasil observasi, indikator capaian dianalisis secara deskripsi berdasarkan temuan yang didapatkan pada proses kegiatan belajar mengajar sehingga kegiatan yang dilakukan oleh mahasiswa dan dosen pengasuh tergambar dengan jelas.

\section{HASIL DAN PEMBAHASAN}

\section{A. Hasil Belajar Menyimak}

Untuk mengukur atau mengevaluasi ada tidaknya peningkatan hasil belajar mahasiswa setelah diterapkan Project Based Learning (PBL), maka diberikan test menyimak yang terdiri atas empat bagian yaitu tekanan (stress), irama (rhythm), jeda (juncture), dan intonasi (Intonation). Test yang diberikan berbentuk tes objektif dengan tipe soal menjodohkan, benar atau salah, dan memberikan penanda pada kata, frasa atau kalimat yang terdiri atas 40 soal. Jenis soal dimodifikasi disetiap tesnya dengan tetap memperhitungkan tingkat kesulitan yang sama. Berdasarkan hasil test yang diberikan di setiap siklus, maka didapatkan data sebagaimana diringkas dalam tabel berikut:

Tabel 1. Hasil Belajar Menyimak Mahasiswa

\begin{tabular}{|c|c|c|c|c|}
\hline \multicolumn{2}{|c|}{ Skala Penilaian } & \multirow[t]{2}{*}{ Pre-Tes } & \multirow{2}{*}{$\begin{array}{c}\text { Post-Tes } \\
\text { Siklus } 1\end{array}$} & \multirow{2}{*}{$\begin{array}{c}\text { Post-Tes } \\
\text { Siklus } 2\end{array}$} \\
\hline Kualitatif & Kuantitatif & & & \\
\hline $\mathrm{A}$ & $85-100$ & 0 & 2 & 4 \\
\hline A- & $80-84.99$ & 1 & 3 & 6 \\
\hline $\mathrm{B}+$ & $75-79.99$ & 3 & 6 & 8 \\
\hline B & $70-74.99$ & 6 & 5 & 8 \\
\hline B- & $65-69.99$ & 5 & 6 & 8 \\
\hline $\mathrm{C}+$ & $60-64.99$ & 5 & 8 & 6 \\
\hline $\mathrm{C}$ & $55-59.99$ & 10 & 7 & 2 \\
\hline $\mathrm{D}$ & $50-54.99$ & 8 & 3 & 1 \\
\hline $\mathrm{E}$ & $<49.99$ & 6 & 4 & 1 \\
\hline
\end{tabular}




\begin{tabular}{|c|c|c|c|}
\hline Skala Penilaian & \multirow[t]{2}{*}{ Pre-Tes } & \multirow{2}{*}{$\begin{array}{c}\text { Post-Tes } \\
\text { Siklus } 1\end{array}$} & \multirow{2}{*}{$\begin{array}{c}\text { Post-Tes } \\
\text { Siklus } 2\end{array}$} \\
\hline Kualitatif $\quad$ Kuantitatif & & & \\
\hline Jumlah & 44 & 44 & 44 \\
\hline
\end{tabular}

Berdasarkan tabel 1 di atas, dapat dijelaskan bahwa ada peningkatan hasil belajar mahasiswa dengan menerapkan Project Based Learning pada pembelajaran menyimak bagian-bagian pelafalan. Hal ini dapat dilihat dari berkurangnya jumlah mahasiswa yang tidak mencapai nilai ketuntasan (60 atau $\mathrm{C}+$ ) dari sebelum diterapkannya PBL yaitu 24 orang atau 55\% pada pre-tes, hingga setelah diterapkannya PBL pada siklus 1 menjadi 14 orang atau 32\%, dan 4 orang atau 9\% pada siklus 2. Hal tersebut menunjukkan bahwa penelitian ini berhasil. Untuk lebih jelasnya, persentase peningkatan hasil belajar mahasiswa pada tiap-tiap tes dapat dilihat pada tabel 2 berikut.

Tabel 2. Persentase Ketuntasan Menyimak Mahasiswa

\begin{tabular}{lcccccc}
\hline \multirow{2}{*}{ Ketuntasan } & \multicolumn{2}{c}{ Pre-Tes } & \multicolumn{2}{c}{ Post-Tes Siklus 1 } & \multicolumn{2}{c}{ Post Test Siklus 2 } \\
\cline { 2 - 7 } & $\boldsymbol{F}$ & $\boldsymbol{\%}$ & $\boldsymbol{F}$ & $\boldsymbol{\%}$ & $\boldsymbol{F}$ & $\boldsymbol{\%}$ \\
\hline Tuntas & 20 & 45 & 30 & 68 & 40 & 91 \\
\hline Tidak Tuntas & 24 & 55 & 14 & 32 & 4 & 9 \\
\hline
\end{tabular}

Catatan: F singkatan dari Frekuensi

Dari tabel 2 di atas, dapat disimpulkan bahwa pada pre-tes, terdapat 20 mahasiswa yang memperoleh nilai lebih besar sama dengan 60 atau kategori $\mathrm{C}+$, dengan persentase ketuntasan hasil belajar hanya mencapai 45\%. Hal ini menunjukkan bahwa lebih dari separuh jumlah mahasiwa tidak memahami materi bagian-bagian pelafalan. Kemudian diterapkan Project Based Learning pada proses pembelajaran, pada siklus pertama yang membuahkan peningkatan sebanyak $23 \%$, yaitu 30 mahasiswa memperoleh nilai lebih besar sama dengan 60, dengan persentase ketuntasan belajar 68\%. Persentase ini belum mencukupi standar ketuntasan belajar kelas, yaitu $80 \%$, sehingga dilanjutkan ke siklus berikutnya. Pada siklus kedua, standar ketuntasan kelas berhasil diraih, yaitu 91\% dengan 40 orang mahasiswa memperoleh nilai lebih besar sama dengan 60. Hal ini mengindikasikan bahwa penelitian ini berhasil. Penerapan PBL dalam pembelajaran menyimak 
bagian-bagian pelafalan berhasil meningkatkan hasil belajar mahasiswa dari $45 \%$ sebelum diterapkan menjadi $91 \%$ setelah diterapkan pada siklus kedua. Untuk lebih jelasnya dapat dilihat pada gambar 1 di bawah ini.

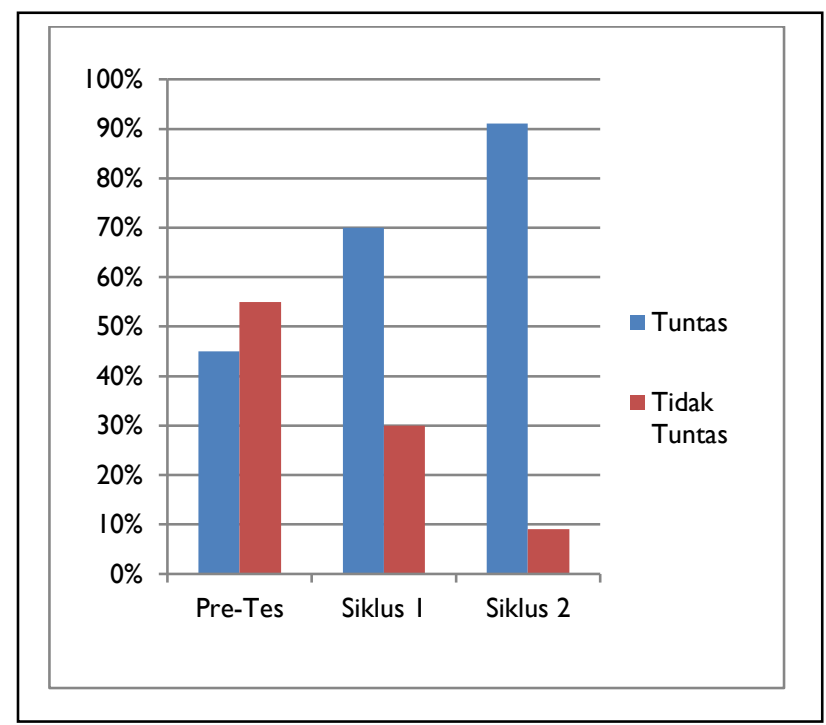

Gambar 1. Persentase Ketuntasan Belajar Menyimak Mahasiswa

Penerapan Project Based Learning tidak hanya menunjukkan peningkatan hasil belajar dan ketuntasan belajar menyimak mahasiswa pada materi bagianbagian pelafalan secara keseluruhan tetapi juga pada bagian-bagian sub materi itu sendiri, yaitu tekanan (stress), irama (rhythm), jeda (juncture), dan intonasi (intonation). Peningkatan ini tampak pada hasil post-tes siklus 1 dan post-tes siklus 2, dimana pada setiap sub materi menunjukkan peningkatan pemahaman yang cukup berarti bagi mahasiswa. Detil dari hasil tes di tiap-tiap sub materi dapat dilihat dari tabel 3 berikut.

Tabel 3. Tingkat Pemahaman Menyimak Bagian-bagian Pelafalan

\begin{tabular}{lccc}
\hline \multicolumn{1}{c}{ Bagian-bagian } & \multicolumn{3}{c}{ Persentase Pemahaman Mahasiswa } \\
\cline { 2 - 4 } Pelafalan & Pre-Tes & Siklus $\mathbf{~}$ & Siklus 2 \\
\hline Tekanan $($ Stress) & 52 & 68 & 91 \\
\hline Irama (Rhythm) & 34 & 66 & 88 \\
\hline Jeda (Juncture) & 45 & 70 & 91 \\
\hline Intonasi (Intonation) & 50 & 75 & 93 \\
\hline
\end{tabular}


Berdasarkan tabel 3 di atas, tingkat pemahaman mahasiswa pada tekanan (stress) meningkat dari 52\% pada pre-tes menjadi 68\% pada post-tes siklus 1 dan 91\% pada posst test siklus 2. Pemahaman menyimak irama (rhythm) dari $34 \%$ pada pre-tes menjadi $66 \%$ pada post-tes siklus 1 , dan $88 \%$ pada post-tes siklus 2 . Kemudian pada pemahaman menyimak jeda (juncture), dari $45 \%$ pada pre-tes meningkat menjadi $70 \%$ pada post-tes siklus 1 , dan $91 \%$ pada siklus 2 . Terakhir, pada pemahaman menyimak intonasi (intonation), dari $50 \%$ pada pre-tes, menjadi $75 \%$ pada post-test siklus 1, dan meningkat menjadi $93 \%$ pada post tes siklus 2 . Peningkatan tersebut dapat dilihat lebih jelas pada gambar 2 berikut.

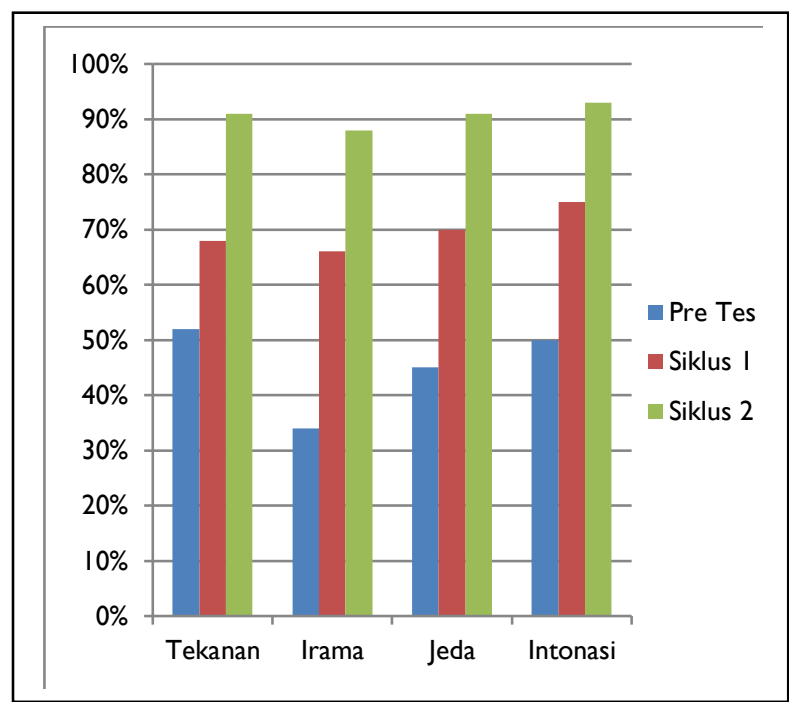

Gambar 2. Persentase Tingkat Pemahaman Mahasiswa pada Bagian-bagian

B. Hasil Pengamatan (Observasi) Pelafalan.

Pengamatan dilakukan selama proses belajar mengajar materi menyimak bagian-bagian pelafalan dilakukan, yaitu untuk 3 kali pertemuan, atau 3x 100 menit. pada pertemuan pertama. Pada pertemuan pertama, untuk mengetahui tingkat kemampuan awal pemahaman mahasiswa terhadap bagian-bagian pelafalan, mahasiswa diberikan pre-tes. Selama proses pre-tes berlangsung, peneliti melakukan pengamatan langsung pada setiap mahasiswa. Mahasiswa terlihat kebingungan dalam mengerjakan tes yang diberikan. Sebagian dari mereka sama sekali mengerti apa yang harus dikerjakan. Mereka menjawab soal berdasarkan 
intuisi saja. Setelah tes selessai diberikan, peneliti sebagai implementator memberikan pertanyaan seputar materi yang akan diberikan, yaitu menyimak bagian-bagian dari pelafalan. Pada umumnya mereka tidak mengerti apa yang dimaksud dengan bagian-bagian pelafalan dan fungsinya dalam proses menyimak dikarenakan dalam bahasa Indonesia tidak semua bagian-bagian pelafalan tersebut dianggap penting dan merubah arti. Peneliti kemudian menjelaskan, memberikan contoh, serta memberikan soal latihan untuk setiap bagian-bagian pelafalan, yang selanjutnya dibahas bersama dengan mahasiswa. Hasil kegiatan ini menunjukkan masih banyak mahasiswa yang belum memahami materi tersebut. Untuk itu peneliti kemudian mengubah strategi pembelajaran dari menjelaskan, memberikan contoh, kemudian mengerjakan soal latihan bersama , menjadi menerapkan Project Based Learning. Siklus pertama pada penelitian inipun dimulai.

Peneliti kemudian menjelaskan tentang Project Based Learning, dan selanjutnya memberikan tugas kepada mahasiswa menjadi delapan kelompok kecil dengan pecahan sub materi tersendiri. Setiap kelompok diminta untuk mencari penjelasan, fungsi dari sub materi yang diberikan, memberikan contoh dalam kata, frasa, dan kalimat sederhana yang disajikan dalam bentuk lisan. Setiap kelompok diminta untuk mencari rujukan secara daring tentang bagian-bagian pelafalan, mencari bahan audio dan video yang berhubungan dengan materi mereka, menyiapkan soal latihan beserta jawaban yang akan dipresentasikan di pertemuan kedua pada minggu berikutnya.

Pada pertemuan kedua, hasil kerja kelompok yang terpilih dipresentasikan. Kelompok yang melakukan presentasi bertindak sebagai tutor, sedangkan kelompok lainnya bertindak sebagai peserta. Pada pertemuan ini, terlihat seluruh mahasiswa antusias mengikuti kegiatan ini. Mereka mulai memahami materi yang diajarkan, dan mencari lebih banyak lagi rujukan yang berhubungan dengan penggunaan stress, irama, jeda, dan intonasi dalam teks lisan bahasa Inggris. Pemahamanpun diperoleh dengan sendirinya. Peneliti hanya bertindak untuk memberikan penjelasan tambahan seperti perbandingan dalam bahasa Indonesia. 377 
Penilaian teman sejawat juga dilakukan dalam menilai jawaban dari soal-soal yang diberikan. Di akhir pertemuan, peneliti kembali memberikan post-tes. Hasil posttes menunjukkan kemajuan yang berarti, yaitu ketuntasan sejauh $70 \%$ namun belum mencapai standar ketuntasan kelas yaitu 80\%, sehingga dilanjutkan ke siklus berikutnya, yaitu siklus kedua.

Pada pertemuan III Siklus II, Peneliti mengamati adanya perubahan yang lebih dramatis setelah mahasiswa melihat hasil Post Test pada siklus I di pertemuan II. Mahasiswa menjadi lebih aktif dan tertarik dalam mempelajari materi tersebut. Mahasiswa yang telah tuntas memberikan dampak positif terhadap reaksi mahasiswa yang belum tuntas pada pertemuan sebelumnya. Mereka saling memotivasi, dan bertukar bahan yang telah mereka dapatkan, belajar bersama, dan tak sungkan untuk bertanya ataupun beradu pendapat. Mereka melihat dan membahas kembali materi yang mereka peroleh berupa video, tutorial, mendengarkan audio yang telah mereka unduh sebelumnya. Sebagian dari mereka ternyata mencari lebih banyak lagi materi-materi berupa teks lisan dan juga bukubuku rujukan untuk memperdalam materi menyimak bagian-bagian dari pelafalan yang erat dengan materi mata kuliah lainnya seperti Fonologi. Diakhir pertemuan, peneliti melakukan post tes terakhir untuk mengambil nilai hasil belajar mahasiswa. Hasilnya sungguh menggembirakan, berdasarkan keseriusan belajar mahasiswa diperoleh hasil post test mahasiswa tuntas mencapai $91 \%$.

\section{SIMPULAN}

Berdasarkan hasil analisis data pada penelitian ini, maka dapat disimpulkan bahwa Project Based Learning pada pembelajaran menyimak bagian-bagian dari pelafalan dapat meningkatkan hasil belajar dan pemahaman mahasiswa terhadap materi yang diberikan; tekanan (stress), irama (rhythm), jeda (juncture), dan intonasi (intonation) pada kata, frasa, dan kalimat sederhana yang disajikan secara lisan. Hal ini dibuktikan dengan meningkatnya hasil ketuntasan belajar mahasiswa yang semula hanya $45 \%$ pada pre-tes, menjadi $70 \%$ pada post test siklus pertama, dan $91 \%$ pada post test siklus kedua. Selain itu, penerapan Project Based Learning dalam pembelajaran juga meningkatkan rasa ingin tahu dan ketertarikan pada 
materi tersebut dengan mencari sumber-sumber rujukan yang sesuai dengan sendirinya, serta sama-sama belajar dan berlatih dengan bahan yang didapatkan berupa video, tutorial, teks lisan maupun tulisan.

\section{DAFTAR PUSTAKA}

Cohen, L., L.Manion, dan K.Morrison. 2007. Research Methods in Education. New York: Routledge.

Ismayani, Ani, dan Nuryanti. 2016. "Penerapan Project Based Learning dalam Pembelajaran Matematika untuk Meningkatkan Kemampuan Komunikasi Matematis dan Aktivitas Belajar'. Makalah dalam Konferensi Nasional Penelitian Matematika dan Pembelajarannya (KNPMP II). Surakarta: Universitas Muhammadiyah Surakarta.

Lisminingsih. 2010. Pembelajaran berbasis Proyek: Alternatif Model pendidikan Lingkungan Hidup untuk Meningkatkan Kecakapan Hidup. Jurnal Paradigma, Tahun XV, Nomor 30, Edisi Juli-Desember. IKIP Budi Utomo. Malang.

Manurung, Imelda Darmayanti. 2016. "Project Based Learning Technique on the Student's Listening Achievement". Makalah dalam The $8^{\text {th }}$ COTEFL, International Conference on Teaching English as a Foreign Language. Medan: UMSU Press.

Suhartatik, dan Adi. 2014. "Pengembangan Model Project-Based learning Untuk Meningkatkan Kemampuan Bahasa Inggris Siswa Ponpes Modern di Malang Raya. Artikel dalam Jurnal LiNGUA, Vol. 9, No.2, Desember 2014. Malang: Universitas Maulana Malik Ibrahim.

Paizaluddin, E. 2013. Penelitian Tindakan Kelas. Jakarta: Alfabeta. 